\title{
MENILIK PEREMPUAN SEBAGAI SOCIAL CLIMBER DALAM PANDANGAN EKONOMI ISLAM
}

\author{
Nurudin \& Muyassarah \\ Universitas Islam Negeri (UIN) Walisongo Semarang \\ nurudin@walisongo.ac.id - muyassarah@walisongo.ac.id
}

\begin{abstract}
Abstrak
Social climber is described as a person who is eager to gain a higher social status in his or her society. In the globalization era, many women show off their styles that are not in accordance with their belongings. Those who look glamorous do not pay attention to the Islamic economic value. Therefore how women restrict the future generations not to be excessive in appearing their performance to avoid undesirable social and psychological impacts. Principally, Islam does not justify social climber because in Islamic economics istishod is recognized as the balance between the world and the hereafter which is in line with the Islamic economic goal namely alfalah. It means a balanced luck between the world and the hereafter. But it does not mean showing off glamorous behaviour in the world as such so it causes jealousy among the surrounding environment and induces criminals to commit crime such as theft, robbery and others. Social climber is also regarded as isrof means extravagance. Islamic economics forbids people to live extravagantly and miserly regardless of its impact because Islamic economics advocate simple life.
\end{abstract}

Social climber digambarkan sebagai seseorang yang ingin mendapatkan status sosial yang lebih tinggi di sekitarnya. Dalam kondisi zaman globalisasi banyak perempuan yang bergaya pamer tidak sesuai dengan kondisi materi yang dimilikinya. Mereka yang berpenampilan glamor tidak memperhatikan nilai-nilai ekonomi Islam. Oleh karena itu bagaimana para perempuan membatasi agar generasi-generasi mendatang tidak berlebihan dalam berpenampilan untuk menghindari dampak sosial dan psikologi yg tidak diinginkan. Pada prinsipnya, Islam tidak membenarkan social climber karena di dalam ekonomi Islam dikenal istilah istishod yakni keseimbangan antara dunia dan akhirat yang sejalan dengan tujuan ekonomi Islam yang disebut al-falah. Artinya keberuntungan yang seimbang antara dunia dan akhirat, jangan hanya untung dunia yang justru pamer atau berperilaku glamor yang menyebabkan kecemburuan lingkungan sekitar dan mengundang penjahat melakukan kejahatan misalnya pencurian, perampokan dan lain-lain. 
Social climber juga termasuk isrof yakni pemborosan. Ekonomi Islam melarang hidup boros berfoya-foya dan kikir tanpa memperhatikan dampaknya karena ekonomi Islam menganjurkan hidup sederhana.

Kata Kunci: perempuan; social climber; ekonomi Islam

\section{A. Pendahuluan}

Berbicara tentang kebutuhan sehari-hari manusia, tidak terlepas dengan harta benda yang sifatnya material untuk memenuhi kebutuhan hidup yang dilakukan dengan cara berbelanja. Belanja merupakan kata yang biasa digunakan sehari-hari dalam konteks transaksi perekonomian yang sering di identikkan dengan kebutuhan ibu rumah tangga maupun single. Pada cerminan ini, gaya hidup berbelanja dan rekreasi pada masyarakat dengan kelas tertentu, didukung keadaan ekonomi tertentu pula. Rata-rata perempuan yang suka shoping karena sifat perempuan royal, kondisi seperti itu perempuan mengikuti want semata yang menuruti hawa nafsunya sebagai perempuan yang pengenan.

Belanja juga merupakan sebuah kegiatan ekonomi yang juga berbentuk kegiatan konsumtif, di mana dalam waktu tertentu masyarakat menggunakan, mengkonsumsi barang pada saat tertentu juga. Dalam perspektif ilmu ekonomi klasik konsumsi merupakan dinamika dari individu-individu yang memaksimalkan kepuasan mereka melalui pembelian berbagai benda-benda yang cakupannya selalu semakin banyak. Kondisi tersebut menjadikan konsumsi sebagai objek dari semua produksi. ${ }^{1}$ Berbicara dengan kegiatan konsumsi, Indonesia merupakan Negara yang dikenal konsumtif. Dalam rentang waktu 1970-an hingga saat ini, masyarakat Indonesia sudah dikenal sebagai masyarakat yang paling konsumtif di dunia. Hal ini semakin berkembang pada sekitar tahun 1998-an hingga tahun 2008-an sebagai dampak krisis moneter di Indonesia. Peningkatan sebutan sebagai negara konsumtif di dunia, rupanya tidak berpengaruh dalam masyarakat Indonesia. Keadaan ini bukan hanya terjadi di dalam negeri, akan tetapi tetap berlangsung di luar negeri juga.

Kegiatan konsumtif secara ekonomi bukan hanya melalui transaksi jual beli yang konvensional saja akan tetapi berubah trend dengan adanya e-commerce.

${ }^{1}$ Mike Featherstone, Postmodernisme dan Budaya Konsumen, terj. Misbah Z. Elisabeth (Yogyakarta: Pustaka Pelajar, 2001), h. 31. 
Dirilis dari salah satu situs jual beli online yaitu Tokopedia, sekitar tahun 2014 didapatkan data 66.28 persen dari 5,3 juta barang yang berada di display terjual dibeli oleh kaum wanita. Dari presentasi tersebut, ada sekitar 46,33 persen pembeli wanita dengan umur 20 hingga 29 tahun. Sedangkan kebanyakan produk yang laku adalah perhiasan dan produk kecantikan atau kesehatan. ${ }^{2}$ Kemampuan untuk membeli suatu barang tertentu merupakan wujud kemampuan seseorang secara ekonomi. Karena membeli itu merupakan salah satu motivasi memegang uang yakni motivasi memegang uang untuk bertransaksi. Seseorang yang bisa membeli barang dengan brand ternama bahkan berasal dari luar negeri dianggap sebagai seorang yang lebih mempunyai kelas.

Polarisasi tentang sifat konsumsi dalam masyarakat yang mengalami modernisasi kelas tinggi sangat jelas terasa dan mengalami kompleksitas bentuk. Konsumsi bukan lagi sekedar nafsu untuk membeli banyak komoditas, satu fungsi kenikmatan, satu fungsi individual, pembebasan kebutuhan, pemuasan diri, kekayaan atau konsumsi atas sebuah objek. Konsumsi telah menjadi satu sistem atau kode tanda, sebagai tatanan manipulasi tanda, manipulasi objek sebagai tanda, sistem komunikasi (seperti bahasa), sistem pertukaran, moralitas dan satu sistem pertukaran ideologis. Setiap aktornya akan mengalami proses isolasi atas yang lain dan individualisasi. Konsumsi telah menjadi pengendali alam bawah sadar setiap orang, baik sebagai sistem tanda maupun sistem sosio-ekonomikopolitik bahkan ia telah menjadi logika sosial. ${ }^{3}$ Konsumsi merupakan kebutuhan primer yang penting, namun juga harus memiliki batasan-batasan tertentu.

Maraknya globalisasi diberbagai bidang, turut membawa perubahan pada gaya hidup masyarakat. Media sosial sering dianggap media yang paling efektif dalam memberikan informasi bahkan menggerakkan massa. Publikasi melalui media sosial juga merupakan cara yang ampuh dalam mendapatkan simpati massa. ${ }^{4}$ Orang yang mempublikasikan kemampuan dalam membeli barang pun

\footnotetext{
${ }^{2} \mathrm{http}: / /$ www.cnnindonesia.com/gaya-hidup/perempuan-ternyata-tidak-meluluberperilaku-konsumtif/

${ }^{3}$ Ritzer, Pengantar, dalam Jean Baudrillard, Masyarakat Konsumsi, terjemahan Wahyunto (Yogyakarta: Kreasi Wacana, 2004), h. xxxiv.

${ }^{4}$ Lihat kembali teori jarum suntik (hypodermic injection) yang menyebutkan bahwa media massa yang efektif dapat yang dapat menimbulkan efek yang kuat, langsung, terarah, dan segera. Wiryanto, Teori Komunikasi Massa, (Jakarta: Grasindo, 2000), h. 3.
} 
mendapat pengakuan dengan instan. Parahnya orang yang mempublikasikan melalui media sosial ini tak jarang mereka bukanlah seorang yang berkedudukan atau yang mempunyai materi sehingga disebut sebagai social climber. ${ }^{5}$ Penting sekiranya masyarakat menilik wanita dalam komunitasnya sebagai kaum yang rentan kepada tindakan ini, sehingga perlu dikemukakan lebih lanjut bagaimana pandangan Islam terkait social climber.

\section{B. Perempuan Social Climber}

Social climber merupakan kelompok orang yang mencari pengakuan. Social climber lebih tinggi dari status yang sebenarnya. Kalau secara sederhananya social climber sebagai seorang yang berusaha menaikkan status sosialnya dengan usaha tertentu. ${ }^{6}$ Semua orang ingin statusnya naik setiap waktu tetapi social climber tidak berusaha meraihnya dengan prestasi dirinya, tapi dengan simbol yakni aksesoris yang dipakainya atau yang menempel pada dirinya. Memang semua perempuan ingin status sosialnya naik. Sayangnya social climber tidak peduli dengan proses untuk naik ke status sosial yang lebih tinggi, perempuan-perempuan tersebut menjadi is the best.

Yang mencolok dari social climber tentu saja lifestyle. Sangat ironis sekali di lingkungan mahasiswa banyak yang menjadi social climber dengan gaya hidup hebring ternyata latar belakang miskin, tentu fenomena ini membuat kaget banyak mahasiswa yang kesehariannya terlihat trendi setiap penampilannya, akan tetapi pada saat seleksi beasiswa mahasiswa tersebut ternyata dari latar belakang keluarga miskin. Padahal orang sukses, kemewahan, eksistensi dan segala fasilitas yang ada harus merupakan berkah dan hasil dari kerja keras atau reward dari segala kerja keras yang telah mereka lakukan, sehingga sukses itu butuh proses tidak instan. Social climber yang diharapkan adalah kemewahan dan terkenal merupakan suatu kebutuhan dan keharusan.

${ }^{5}$ http://solo.tribunnews.com/2017/05/07/hobi-pamer-dan-sok-kaya-di-sosial-media-hatihati-bisa-jadi-kamu-masuk-golongan-social-climber

${ }^{6}$ Awalnya latar belakangnya dari kelas menengah berusaha untuk masuk ke lingkungan sosialita, mulai meniru gaya hidup dari sosialita, mulai dari berusaha memakai pakaian branded kemudian berusaha bergaul dengan ala-ala sosialita contohnya dalam masyarakat arisan berlian kemudian berujung arisan bodong. Sehingga social climber ingin mendapatkan sebuah pengakuan. Jika climbernya ala mahasiswa tidak ada masalah karena fasilitasnya dipenuhi orang tuanya, sehingga tidak terlalu pusing kalau mahasiswa menggunakan uang orang tuanya dengan berhura-hura. 
Kondisi saat ini banyak remaja membawa gadget meskipun sebagai social climber belum membutuhkan atau belum mampu untuk membeli gadget-gadget mahal. Akibatnya mereka merasa galau dan ingin cepat memperolehnya, karena jika belum memperolehnya dianggap tidak keren, cool dan menarik perhatian lingkungan sekitarnya. Fasilitas berbanding lurus dengan rasa percaya diri, tidak punya fasilitas mewah atau bagus akan menjadi minder, tetapi jika mempunyai fasilitas mewah atau bagus langsung menjadi percaya diri.

Pada fenomena ini perempuan cenderung social climber karena ingin diakui oleh kelompoknya, dimana perempuan dalam komunitas adalah eksistensi yang merupakan sesuatu keharusan untuk menambah percaya diri. Ciri social climber tidak bagus karena memaksakan diri untuk mendapatkan segala fasilitas mewah supaya disebut keren, gaul dan segudang pujian dari komunitas maupun di luar komunitasnya. Sayangnya sosial climber mendapatkan fasilitasnya masih minta uang kepada orang tua dengan cara memaksa guna untuk memenuhi kebutuhan yang diinginkan, misalnya HP, pakaian yang dipakai maupun motor yang dipakai harus yang berkelas.

Sigmund Freud juga mengklaim bahwa social climber sangat mempengaruhi aspek biologis dan aspek psikologis setiap perempuan dan berpengaruh pada kemampuan dan peran sosialnya. Doktrin Freudian ini berkembang luas, .yang kemudian dianut oleh banyak kalangan, dan menjadi pedoman dan acuan bagi para pendidik, pekerja sosial maupun politisi. ${ }^{7}$ Oleh karena itu, banyak di antara perempuan berkumpul dalam sebuah komunitas dengan kesamaan aspek secara psikologis, maka semua perempuan dalam komunitas tersebut memiliki gaya pamer yang sama, sehingga kelihatan sekali komunitas tersebut bersaing dalam hal yang melekat pada diri perempuan dalam komunitasnya. Komunitas tak jarang sebagai sarana menyalurkan hobi berorganisasi bahkan sebagai sarana curhat terhadap apa yang dirasakan, dari persoalan sosial hingga masalah rumah tangga pribadinya. Kejadian ini sering terjadi pertengkaran bahkan persaingan tidak sehat yang pada akhirnya masalah pribadi tersebut tersebar di internal maupun eksternal komunitas. Biasanya perempuan yang sering melakukan social climber yang memaksakan diri untuk masuk ke status sosial yang lebih tinggi hanya demi mendapatkan pengakuan.

${ }^{7}$ Kamla Bhasin, Menggugat Patriarki, Pengantar tentang Persoalan Dominasi terhadap Kaum Perempuan, (Yogyakarta: Yayasan Bentang Budaya, 1996), h. 30. 
Lingkungan masyarakat yang bersifat social climber gaya hidupnya penuh persaingan dan membentuk kader-kader generasi muda yang semakin social climber semakin eksis dan lestari. Oleh karena itu gaya social climber perlu diminimalisir agar gaya hidup yang sederhana tertanam pada lingkungan masyarakat tersebut.

Dengan adanya globalisasi diberbagai bidang termasuk bisnis bahkan gaya hidup yang semakin hari banyak orang pola hidupnya serba glamor bahkan pamer tak bisa dibendung terhadap sesama manusia. Social climber akan mempengaruhi seseorang untuk ikut berbuat apa yang dilihat dari penampilan temanya. Maraknya kaum sosialita sebagai komunitas juga mempengaruhi kehidupan sosial masyarakat. Dalam hal ini kaum sosialita selalu digambarkan pada sosok yang penuh dengan kemewahan dan keglamoran sehingga menandakan secara umum gaya hidup sosialita yang menjadikan ciri khas mereka sendiri. Dalam penelitian yang dilakukan Maria Disa Artika, "Social Climber sebagai Fenomena Komunikasi: Studi Deskriptif di Kalangan Perantau Domestik yang Berdomestik di Bali" yang mengatakan bahwa konsumsi yang meliputi tanda, simbol dan nilai dapat digunakan untuk memisahkan satu kelompok dengan kelompok sosial yang lain. ${ }^{8}$ Maraknya kegiatan para sosialita yang selalu mempublikasikan strata sosial mereka, bahkan dalam berbagai kegiatan para sosialita ini menjadi social climber yang haus akan publikasi dan pengakuan setiap saat.

\section{Peran Perempuan terhadap Sosial Climberdalam Pandangan Ekonomi Islam}

Social climber merupakan perilaku ekonomi yang dilarang dalam syariah karena jelas bertentangan dengan sifat kesederhanaan dan kerendahan hati seseorang baik dihadapan personal manusia maupun kelompok manusia. Kegiatan ekonomi hendaknya berorientasi pada ibadah pada Allah semata, ${ }^{9}$ social climber merupakan sifat membanggakan yang dipakai atau yang dimiliki serba mewah yang berorientasi pada kebendaan semata. Berbangga dengan yang dimiliki memang bukanlah sebuah hal yang lazim dilakukan. Perbuatan ini juga dilarang oleh Allah karena bertentangan dengan QS. al-Takatsur [102] ayat 1-8: 30.

${ }^{8}$ Adiwarman A. Karim, Ekonomi Mikro Islami, (Jakarta: Raja Grafindo Persada, 2015), h.

${ }^{9}$ Abdul Azmi Islahi, Economic Concepts of Ibn Taimiyah (London: The Islamic Foundation, 1988), h.176. 


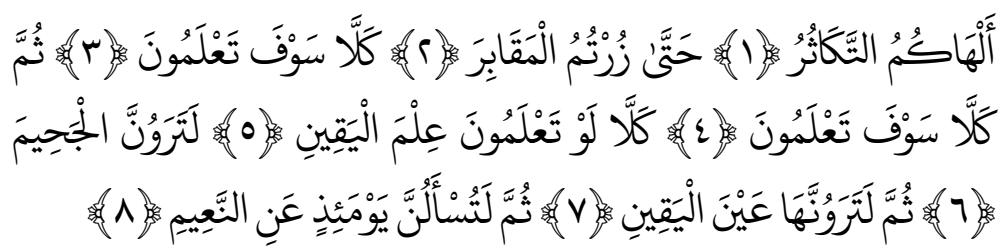

"Bermegah-megahan telah melalaikan kamu, sampai kamu masuk ke dalam kubur. Janganlah begitu, kelak kamu akan mengetahui (akibat perbuatanmu itu), dan janganlah begitu, kelak kamu akan mengetahui. Janganlah begitu, jika kamu mengetahui dengan pengetahuan yang yakin, niscaya kamu benar-benar akan melihat neraka Jahiim, dan sesungguhnya kamu benar-benar akan melihatnya dengan 'ainul yaqin. Kemudian kamu pasti akan ditanyai pada hari itu tentang kenikmatan (yang kamu megah-megahkan di dunia itu)."

Secara tidak langsung, ayat diatas menunjukkan bahwa memang terjadi kelalaian pada orang-orang yang beribadah kepada Allah. Padahal hakikatnya manusia diciptakan oleh Allah untuk beribadah. Beribadah yang dimaksud dalam surat ini adalah berusaha melaksanakan apa yang menjadi perintah Allah, sedangkan meninggalkan ibadah kepada selain Allah yang dimaksud adalah mendahulukan apa yang dicintai selain Allah, yaitu keadaan duniawi dengan bermegah-megahan yang bersifat keduniawian. Maka perempuan sebagai ibu atau calon ibu sebagai tolok ukur kebaikan suatu bangsa termasuk kesejahteraan ekonomi. Oleh karena itu perempuan harus bisa memberikan contoh yang baik termasuk hidup sederhana karena perempuan sebagai pendidik pertama dan utama bagi anak untuk regenerasi yang akan datang. ${ }^{10}$ social climber merupakan sesuatu yang bahaya yang perlu di hilangkan oleh setiap muslim, karena orang Islam yang mampu secara fasilitas untuk memenuhi kebutuhan karena memang ia orang kaya, namun dalam Islam orang yang dianggap sukses bukan berarti harus bermegah-megahan. Muslim yang baik harus lebih bijak dalam memaknai kehidupan modern. Sukses butuh proses yang cukup panjang yang tetap riel norma syariah yang cenderung lebih wibawa dan bertaqwa yang lebih berorientasi pada pengentasan kemiskinan dan menuntaskan penyebab kemiskinan. ${ }^{11}$ Social climber bisa dialihkan ke hal-hal yang positif yang lebih falah sehingga

${ }^{10}$ Mansur, Pendidikan Anak Usia Dini dalam Islam, (Yogyakarta:Pustaka Pelajar,2005), h. 2.

${ }^{11}$ Yusuf Qardhawi, Spektrum Zakat dalam Membangun Ekonomi Kerakyatan, (Jakarta: Zikrul Hakim, 2005), h. 30. 
dapat membantu orang yang berada dibawahnya dalam ukuran harta yang dimiliki, artinya mampu membantu sebagai muzakki yang mengentaskan kemiskinan itu lebih mulia dari pada pamer. Orang miskin bisa berubah menjadi posisi muzakki itu merupakan kegiatan yang positif, dalam Islam perbuatan yang bersifat positif merupakan ibadah.

Dalam hadis yang artinya wanita itu adalah tiang Negara, jika wanita baik maka baiklah Negara tetapi sebaliknya jika wanita buruk maka buruklah Negara. Maka wanita agar menjadi lebih baik, lebih maju, maka perlu diberdayakan atau ditingkatkan melalui kegiatan yang positif anatara lain PKK, Dharma Wanita, pengajian, Yasin Tahlilan dan lain-lain. Banyaknya organisasi perempuan di masyarakat yang di landasi dengan norma yang berlaku, akan melahirkan insaninsan perempuan yang menjalani hidup dengan menerapkan prinsip-prinsip ekonomi Islam yang bernuansa ibadah karena hanya mencari pengakuan status sosial tidak baik. Social climber lebih bersifat konvensional yang artinya sebagai sesuatu yang sekuler yang berorientasi pada kehidupan duniawi dan sama sekali tidak memasukkan Tuhan serta tanggung jawab manusia kepada Tuhan di akhirat dalam bangun pemikirannya, ${ }^{12}$ ekonomi konvensional berorientasi bebas nilai. Berbeda dengan ekonomi Islam yang lebih dibangun oleh prinsip-prinsip religius yakni hidup berorientasi pada dunia dan akhirat, lain dengan konsumsi konvensional yang hanya bersifat keinginan yang bersifat materi.

Kekuatan dari dalam diri manusia di sebut jiwa atau hawa nafsu, sejalan dengan firman Allah dalam surat al-Syam ayat 7-10 padahal nafsu manusia berbeda-beda, artinya ada beberapa jenis nafsu antara lain nafsu al-amru bissu' yang menyuruh manusia kepada kejahatan dalam surat Yusuf ayat 53, nafsu allauwwamah yang selalu menyesali diri dalam surat al-qiyamah ayat 2 , dan nafsu ath-thumakninah yakni jiwa yang tenang sehingga selalu merasa tentram dengan keyakinan bahwa Allah adalah Tuhannya semata dalam surat al-Fajr ayat 27, jenis-jenis nafsu dapat diperoleh sesuai dengan kualitas kiemanan manusia yang pada akhirnya dapat membedakan terhadap keinginan-keinginannya. Dalam Islam, manusia harus mengendalikan dan mengarahkan want sehingga dapat membawa kemanfaatan dan bukan kerugian bagi manusia di dunia maupun di

\footnotetext{
${ }^{12}$ Adiwarman A. Karim, Ekonomi Mikro Islami, h. 29.
} 
akhirat. Ekonomi Islam lebih bersifat need yakni kebutuhan yang menyesuaikan dengan kemampuan diri sendiri. Oleh karena itu social climber hanya merupakan keinginan yang menuruti hawa nafsunya semata tanpa memperhatikan dampak negatifnya. Social climber gaya hidup perempuan sekarang yang notabenenya sudah menjadi kebutuhan dan tuntutan karena itu merupakan pandangan konvensional yang materialistik hedonistik.

Dalam ekonomi konvensional perilaku konsumsi berdasarkan rasionalisme dan utilitarianisme. Rasionalisme artinya seseorang mengkonsumsi apapun dan mendapatkan apapun boleh saja yang penting seseorang memiliki anggaran yang mencukupi. Walaupun rasionalisme bersifat self interest, perilaku konsumsi tersebut cenderung individualistik sehingga social climber sering kali mengabaikan keseimbangan dan keharmonisan sosial. Dapat dikatakan bahwa prinsip dasar social climber adalah saya bisa memakai apapun yang kupakai dengan harga mahal dan dalam jumlah berapapun sepanjang anggaran yang kumiliki cukup untuk membeli barang yang aku inginkan. ${ }^{13}$ Sedangkan utilitarianisme yakni kepuasan yang bersifat subyektif, misalnya seseorang mengkonsumsi barang atau jasa bertendensi pada pemenuhan want yang memang bersifat subyektif antara orang satu dengan orang lainnya.

Sedangkan dalam pandangan ekonomi Islam penggerak awal kegiatan social climber adalah mengutamakan want bukan need, sehingga hanya menuruti hawa nafsu syaitan belaka. Kegiatan yang dilakukan cukup memiliki anggaran dan memberikan utilitas atau kepuasan bagi pelaku social climber. Namun dalam ekonomi Islam ada hal yang dilarang dan ada hal dianjurkan. social climber dalam ekonomi Islam dilarang karena tidak baik, tidak bernilai bahkan terlarang sehingga akan dijauhi. Selain itu juga terdapat prioritas dalam pemenuhannya berdasarkan tingkat kemaslahatan yang dibutuhkan untuk menunjang kehidupan yang Islami. Ekonomi Islam justru menganjurkan: mengutamakan akhirat dari pada dunia, konsisten dalam prioritas pemenuhan kebutuhan sehari-hari, memperhatikan etika dan norma. ${ }^{14}$

${ }^{13}$ Mustafa dkk, Pengenalan Eksklusif Ekononomi Islam, (Jakarta: Fajar Press, 2006), h. 56.

${ }^{14}$ M.B. Hendrie Anto, Pengantar Ekonomika Mikro Islami (Yogyakarta: Ekonisia UII, 2003), h. 32. 
Social climber jelas tidak sesuai dengan prinsip-prinsip ekonomi Islam. Oleh karena perlu dihilangkan baik dalam keluarga maupun lingkungan masyarakat. Maka perempuan yang melakukan social climber sedapat mungkin dihindari maupun dijauhi, karena akan merusak apa yang sudah kita laksanakan dengan niat ibadah. Semua aktivitas dengan nat ibadah akan rusak semua jika kita melakukan social climber. Social climber tidak pentingnya dan tidak ada manfaatnya sama sekali. Walaupun ada yang mengatakan social climber dapat menimbulkan kepercayaan diri, padahal kepercayaan diri itu merupakan keyakinan hatinya yang bisa membuat kepedaan pada dirinya bukan karena penampilan yang trendi, glamor, serba bermerk dan sejenisnya.

\section{Sosial ClimberTergolong Israf}

Israf atau westefull adalah berlebih-lebihan dalam segala hal telah dilarang dalam syariat Islam. Sebaliknya justru Islam mendorong perilaku sederhana dan rendah hati dalam semua tindakan. ${ }^{15}$ Israf dalam Ekonomi Islam dipandang negatif baik spiritual maupun dalam bidang apapun, bahkan menghasilkan dampak buruk dalam kehidupan di dunia namun sebaliknya jika kesederhanaan dan kerendahan hati juga bukan semata terpuji secara spiritual tetapi juga membawa banyak manfaat bagi kehidupan manusia itu sendiri. Oleh karena itu disinilah peran perempuan sebagai ibu yang memberikan suri tauladan kesederhanaan kepada anak-anaknya dalam keluarga. Social climber berbanding terbalik dengan kesederhanaan dan kerendahan hati, maka social climber sangat dilarang dalam pandangan ekonomi Islam. Kesederhanaan mendorong manusia untuk memanfaatkan sumber daya ekonomi secara lebih efisien, lebih optimal dan lebih adil. Social climber merupakan perilaku israf dalam bertindak untuk pamer agar status sosialnya diakui oleh orang lain. Seluruh sistem dan bentuk praktek ekonomi harus mengarah pada sikap sederhana dan menutup ataupun setidaknya mengurangi kecenderungan perilaku social climber. Oleh karena itu komunitas atau kelompok organisasi yang berpenampilan kekinian yang sifatnya boros berarti jauh dari prinsip-prinsip ekonomi Islam. Sebisa mungkin sifat kesederhaan diimplementasikan manusia dalam bertindak untuk memenuhi kebutuhan sehari-hari.

\footnotetext{
${ }^{15}$ Ibid., h. 40.
} 


\section{E. Social ClimberMeningkatkan Inflasi}

Social climber merupakan perbuatan yang memicu semakin naiknya tingkat inflasi, karena social climber perbuatan pamer agar status sosialnya diakui oleh orang lain walaupun sama sekali anggaran yang dimiliki nol. Artinya tidak ada tapi diada-adakan. Inflasi kenaikan harga barang atau komoditas secara terus menerus dalam suatu perekonomian untu suatu periode tertentu. ${ }^{16}$ Bila terjadi inflasi masyarakat membeli lebih mahal barang/komoditas yang sama, uang menjadi tidak begitu ada harganya. Bila barang tidak terjangkau harganya, masyarakat tidak belanja/tidak kuat membeli atau menahan uangnya sehingga menyebabkan perekonomian terganggu. Para ahli sudah banyak mengkaji tentang penyebab terjadinya inflasi. Satu faktor yang paling mudah dijelaskan kepada kelompok awam adalah soal meningkatnya permintaan yang disebut demand sementara keterbatasan barang yang disebut supply. Barangnya sama, ukuranya sama tetapi harganya lebih mahal yang dirugikan adalah masyarakat kelas bawah yang sangat membutuhkan barang tersebut. Karena inflasi tinggi salah satu pemicunya adalah pola hidup masyarakat yang bersifat konsumstif.

Pada dasarnya seorang Muslim dalam melaksanakan konsumsi lebih berorientasi pada iqtishad yakni berekonomi Islam keseimbangan antara dunia dan akhirat, Allah tidak menghendaki seseorang menghabiskan tenaga dan waktunya untuk beribadah dalam arti sempit, akan tetapi juga harus mengusahakan kehidupannya di dunia. Dalam mengusahakan kehidupan di dunia tidak boleh boros, tetapi juga tidak boleh kikir. Janganlah seseorang terlalu senang terhadap harta, tetapi juga jangan terlalu sedih manakala kekurangan rizki. Muslim yang baik harus minta tolong kepada Allah dengan cara sabar dan mendirikan shalat. Kondisi perempuan yang pamer maupun isrof berarti hidupnya bersifat konvensional yang hanya mementingkan harta benda semata yang berorientasi self interest. Pamer untuk membeli apapun yang diinginkan walaupun barang yang dibeli itu tidak penting bagi dirinya hanya berorientasi menaikkan status sosial akan memicu naiknya inflasi.

Situasi ini tidak sehat bagi perekonomian nasional, bahkan mengakibatkan inflasi tidak terkendali dan ekstrim. Oleh karena itu BI yang bertugas untuk

\footnotetext{
${ }^{16}$ Umer Chapra, Islam dan pembangunan Ekonomi, (Jakarta: Gema Insani, 200), h. 48.
} 
menjaga stabilitas perekonomian dan mengendalikan inflasi, artinya dengan menjaga agar masyarakat tetap mampu membeli dan melindungi masyarakat dari kemadharatan inflasi. Prinsip ekonomi Islam menawarkan cara agar harga tetap stabil dan tidak terjadi inflasi yang berlebihan. Karena inflasi itu merupakan penyakit ekonomi masyarakat modern yang timbul karena keserakahan dan berlebih-lebihan dalam konsumsi atau menaikan status sosialnya dengan memaksakan diri mengkonsumsi barang berharga mahal yang bermerk.

Salah satu faktor penyebab terjadinya inflasi yakni kecintaan berlebihan kepada barang atau komoditas yang sering kali di lakukan oleh kelompok social climber dalam surat al-Isra [17] ayat 26-27:

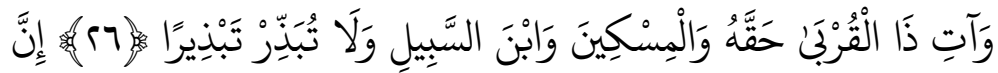

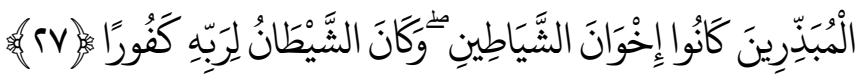

"Dan berikanlah kepada keluarga-keluarga yang dekat akan haknya, kepada orang miskin dan orang yang dalam perjalanan; dan janganlah kamu menghambur-hamburkan (hartamu) secara boros. Sesungguhnya pemboros-pemboros itu adalah saudara-saudara setan dan setan itu adalah sangat ingkar kepada Tuhannya".

Ayat tersebut menjelaskan bahwa hidup yang bermewah-mewahan atau boros dan konsumtif dilarang dalam Islam, lebih-lebih hanya untuk pamer dan pamer termasuk sombong atau riya'. Allah menganjurkan untuk hidup sederhana, tidak boros, tidak kikir dan berendah diri.

Prinsip keseimbangan dalam konsumsi dan memiliki harta menurut Islam ditegaskan pula dalam al-Qur'an surat al-Taubah [9] ayat 34:

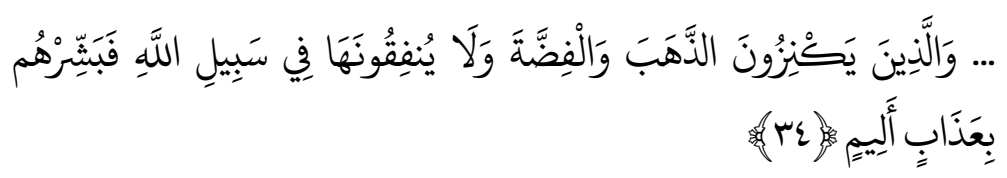

“... dan orang-orang yang menyimpan emas dan perak dan tidak menafkahkannya pada jalan Allah, maka beritahukanlah kepada mereka (bahwa mereka akan mendapat) siksa yang pedih".

Kekayaan yang dimiliki seseorang hendaknya dibelanjakan karena Allah. Ia dilarang untuk dihambur-hamburkan (konsumsi) untuk menuruti hawa nafsu- 
nya. Kemudian Islam juga melarang untuk menyimpannya sebagai kekayaan yang tidak digunakan (diputar) untuk kebaikan. ${ }^{17}$ Oleh karena seorang perempuan yang suka shoping dengan menghambur-hamburkan uangnya dilarang dalam ekonomi Islam. Islam menganjurkan untuk shoping yang bermaslahah agar terhindar dari boros dan kikir.

Salah satu kebaikan seorang Muslim adalah meninggalkan sesuatu yang tidak berguna atau tidak penting dengan kata lain seorang perempuan yang baik tidak membeli sesuatu yang tidak dibutuhkan. Perempuan Muslim yang baik, ia akan bijak dalam berbelanja.

\section{F. Kesimpulan}

Social climber merupakan perbuatan yang berdampak baik pada diri sendiri maupun lingkungan sekitar, karena social climber merupakan tindakan pamer yang memaksakan kondisi keadaan yang sebenarnya artinya bahwa dirinya tergolong orang miskin tapi biar diakui oleh orang lain ia termasuk kategori orang kaya. Oleh karena dengan keberadaan social climber tidak hanya berdampak pada psikologi maupun social namun juga berdampak pada pertumbuhan ekonomi yakni tingkat inflasi akan cenderung naik jika masyarakat berlomba-lomba untuk membeli barang-barang yang sebetulnya tidak kebutuhan primer hanya beli barang dimanfaatkan untuk mengubah status agar di akui oleh kelompoknya atau gengnya. Inflasi yang semakin hari naik dipengaruhi gaya hidup masyarakat yang suka shoping, maka inflasi akan naik terus. Naiknya inflasi, maka pertumbuhan ekonomi yang ditargetkan oleh pemerintah tidak tercapai.

Dalam ekonomi Islam dengan adanya perilaku social climber tidak di benarkan karena justru ekonomi Islam mengharapkan manusia hidup sederhana dan bersahaja. Oleh karena itu social climber dilarang karena ekonomi Islam dikenal dengan istilah iqtishad yang diharapkan seimbang antara dua dan akhirat. Hidup di dunia tidak boleh berlebih-lebihan atau boros tetapi tidak boleh juga kikir. Konsep orang sukses bukan social climber yang harus ditunjukkan secara simbolik kebendaaan yang wah atau branded misalnya dengan memakai HP yang

${ }^{17}$ Muhammad Muslehuddin, Wacana Baru: Manajemen dan Ekonomi Islam, (Yogyakarta: IRCiSoD, 2004), h. 118. 
bermerk, pakaian yang mahal kelas atas, mobil yang mahal agar dianggap orang kaya atau biar di akui status sosialnya oleh orang lain. Konsep sukses adalah orang yang kaya yang mampu mendistribusikan hartanya kepada orang yang berhak menerimanya yakni kepada orang miskin yang disebut mustahik. Orang kaya mampu disebut muzakki yang bisa mengimplementasikan konsep sukses, sehingga sukses bukan pamer namun justru semakin berwibawa, peduli sesama manusia yang disekitar lingkungannya, berdermawan serta lebih memberikan contoh yang baik pada lingkungan.]

\section{Daftar Pustaka}

Anto, M.B. Hendrie, Pengantar Ekonomika Mikro Islami, Yogyakarta: Ekonisia UII, 2003.

Bhasin, Kamla, Menggugat Patriarki, Pengantar tentang Persoalan Dominasi terhadap Kaum Perempuan, Yogyakarta: Yayasan Bentang Budaya, 1996.

Chapra, Umer, Islam dan pembangunan Ekonomi, Jakarta: Gema Insani, 2000.

Featherstone, Mike, Postmodernisme dan Budaya Konsumen, terjemahan Misbah Z. Elisabeth, Yogyakarta: Pustaka Pelajar, 2001.

http://www.cnnindonesia.com/gaya-hidup/perempuan-ternyata-tidak-meluluberperilaku-konsumtif/

http://solo.tribunnews.com/2017/05/07/hobi-pamer-dan-sok-kaya-di-sosialmedia-hati-hati-bisa-jadi-kamu-masuk-golongan-social-climber

Islahi, Abdul Azmi, Economic Concepts of Ibn Taimiyah, London: The Islamic Foundation, 1988.

Karim, Adiwarman A., Ekonomi Mikro Islami, Jakarta: Raja Grafindo Persada, 2015.

Muslehuddin, Muhammad, Wacana Baru: Manajemen dan Ekonomi Islam, Yogyakarta: IRCiSoD, 2004.

Mustafa dkk, Pengenalan EksklusifEkononomi Islam, Jakarta: Fajar Press, 2006.

al-Nabhani, Taqyuddin, Membangun System Ekonomi Alternatif Perspektif Islam, Surabaya: Risalah Gusti, 2002.

Nata, Abuddin, Akhlak Tasawuf dan Karakter Mulia, Jakarta: Raja Grafinda Persada, 2014. 
Qardhawi, Yusuf, Spektrum Zakat dalam Membangun Ekonomi Kerakyatan, Jakarta: Zikrul Hakim, 2005.

Ritzer, pengantar, dalam Jean Baudrillard, Masyarakat Konsumsi, terjemahan Wahyunto, Yogyakarta: Kreasi Wacana, 2004)

Suprayitno, Eko, Ekonomi Islam, Yogyakarta: Graha Ilmu, 2005.

Wiryanto. Teori Komunikasi Massa, Jakarta: Grasindo. 2000. 
